\title{
"I Have an Accent in Every Language I Speak!": Shadow History of One Chinese Family's Multigenerational Transnational Migrations
}

\author{
Jenny Banh $(D)$ \\ Department of Anthropology and Asian American Studies, California State University, Fresno, Fresno, \\ CA 93740, USA; jenbanh@mail.fresnostate.edu
}

Received: 25 March 2019; Accepted: 28 June 2019; Published: 1 July 2019

\begin{abstract}
According to scholar and Professor Wang Gungwu, there are three categories of Chinese overseas documents: formal (archive), practical (print media), and expressive (migrant writings such as poetry). This non-fiction creative essay documents what Edna Bonacich describes as an "middleman minority" family and how we have migrated to four different nation-city states in four generations. Our double minority status in one country where we were discriminated against helped us psychologically survive in another country. My family history ultimately exemplifies the unique position "middleman minority" families have in the countries they migrate to and how the resulting discrimination that often accompanies this position can work as a psychological advantage when going to a new country. We also used our cultural capital to survive in each new country. In particular, this narrative highlights the lasting psychological effects of the transnational migration on future generations. There is a wall of shame, fear, and traumas in my family's migration story that still pervades today. My family deals with everything with silence, obfuscation, and anger. It has taken me twenty years to recollect a story so my own descendants can know where we came from. Thus, this is a shadow history that will add to the literature on Sino-Southeast Asian migration and remigration out to the United States. Specifically, my family's migration began with my grandfather leaving Guangdong, China to Saigon, Vietnam (1935), to Hong Kong, (1969) (then a British Colony), and eventually to the United States (1975). This article explains why my family migrated multiple times across multiple generations before eventually ending up in California. Professor Wang urges librarians, archivists, and scholars to document and preserve the Chinese migrants' expressive desires of migrant experiences and this expressive memoir piece answers that call.
\end{abstract}

Keywords: transnational; migration; Chinese; food genealogy; identity; restaurants

\section{Prologue}

Maxine Hong Kingston starts The Women Warrior with the line, "You must not tell anyone ... what I am about to tell you." (Kingston 1975). On the surface, Kingston's warning is a simple prelude to the disclosure of family secrets; however, her warning also hints at the liberatory power of bearing witness to family history. In that vein, here is my own four-generation clandestine story. My mother also told me not to tell anyone but my marrow screams inside me. I have to write to stop the screaming of both my ancestors and my future descendants.

There is a traditional Chinese belief that says time is not a straight line but instead a circle, like the seasons, and the winds (De Mente 2009; Lipner 2012). ${ }^{1}$ Thus, poems are written for the reader

1 Hindus also believe in circular time. See Das, Subhamoy. "The Concept of Time in Hinduism." Learn Religions. https://www.learnreligions.com/the-concept-of-time-1770059 (accessed on 30 June 2019). 
1000 years in the future or 1000 years from the past. ${ }^{2}$ You can change your past with your poems. I would like to use this essay to save my grandfather. I do hope this letter goes back to my ancestors or ahead to my descendants to tell them I remember them. Viet Nguyen argues that descendants of refugees hold their ancestor traumas in their marrow (Bui 2017) ${ }^{3}$. But am I a refugee from 1000 years ago (or is it 1000 years in the future?). What I know for certain, is that my family transnationally migrated in multiple generations. Sometimes, it was under their own volition and sometimes we fled before the wars engulfed our family. Many of us did not make it, but we survivors did. We are a runner family and we have run for four-generations straight. This is simply one transnational migration story out of millions and I am aware many did not make it out alive.

According to Professor Wang Gungwu, there are three categories of Chinese overseas documents: formal (archive), practical (print media), and expressive (migrant writings such as poetry) (Wang 2002).

\section{Eight-Year-Old Girl}

When I was an eight-year-old kid in Bellevue, Illinois, my eighth-grade-educated father would tell me, "We get treated bad in this place but not as bad as African Americans." My father was not a Marxist or intersectional theorist but he conveyed to me the strange position my Chinese family held in black-and-white Midwest America. We owned a Chinese restaurant that catered to the local working-class population; consequently, we endured the usual racist comments or gestures one would expect given that our four-person family was an island of Chineseness in an ocean of non-Asians. These comments made me think I was a racial minority, but I also had psychological privileges of resilience. Only decades later did I realize that my family occupied what Edna Bonacich calls the "ethnic middlemen" class (Bonacich 1973). Ethnic middlemen are all over the world and often occupy an intermediate status rather than the lowest status. This group tends to concentrate in commerce and trade (Bonacich 1973). Jews in Europe, Chinese in Southeast (SE) Asia, Asians in East Africa, Japanese and Greeks in the United States, etc., are all examples of ethnic middlemen (Bonacich 1973).

Ethnic middlemen are positioned between the consumer and the buyer. Karl Marx called this group Petite Bourgeoisie defined as small-scale traders and shop keepers who manage production (Marx and Engels 2019). He views this group as predatory and an instrument of oppression (Marx and Engels 2019). There has been a lot of historical examples of backlash against these groups from the local populations (Anderson and Anderson 2012). In a world where the masses have little to no opportunities to express their anger against the owners of corporations, ethnic middle man families like mine often bear the brunt of that anger due to the perception of success despite the reality of struggle. Maybe the local population enmity was warranted but I will never know as I was not there. I do not want to get into an oppression Olympics discussion of who was the most mistreated (Hancock 2013). My larger point is that my family occupied a class position that made them despised, but that gave them a cognitive advantage when going to another country where they may also be discriminated against. My family had to transnationally migrate (or run) in each of the last four generations.

Because of the running, each generation had to leave everything behind and start anew with nothing in the new country. Although we did not have economic means, we had psychological bridges in our ancestral blood that we could access in times of need. These psychological privileges have accumulated intergenerationally and are found in my blood. I am not sure of the accuracy of my story because there are so many silent gaps, closed doors and intentional obfuscations from different family members.

2 There are some Chinese people who mark time by decades or generations and not by days. It is well circulated that the Chinese believe they have a five-thousand-year history.

3 See Viet Thanh Nguyen review of Thi Bui (2017). graphic novel The Best We Could Do. 


\section{1915 Guangdong, China}

Yéye 爷爷 (grandfather), who are you? We can never talk about you as Bàba 爸爸 (dad) gets too sad or angry. Baba furiously in Cantonese says, “Don't ever talk about this sad time!" Your life and death created a crater of sadness so big that even three later generations could not fill it. Our family is a sad family and we were always taught to endure, ignore, and run if need be. We rarely laughed as a family and there was a lot of yelling, followed by a long enduring silence. We are a pessimistic family always expecting the worst and predicting downfalls. We trust no one unless they are ethnically Chinese and then, only slightly. We do not even trust each other in our family. In high school, I once (I am not proud of this now) read my jiejie's 姐姐 (older sister) diary and I saw that she wrote letters to you. She met you when she was only a baby. We heard you loved her so much and wanted to keep her in Vietnam but dad did not allow it because of the war. I do not remember what she wrote, but I remember I cried when I read it. I have never met you but you lurk in my blood. It makes me cry still when I think how everything you built was taken away. I know you died the year after you had to give up your companies to the Communists. We have never spoken of how you passed in our family and so this is just a shadow memory of you.

My grandfather was originally from Three Rivers Guangdong, China and moved to Saigon, Vietnam in his late teens. He was part of the historical flow of ethnic Chinese people moving into SE Asia for centuries (Pan 1998; Desai 2009). Grandfather's father and grandfather were turnip farmers. Yeye was born in 1915, Guangdong, China-a politically fractured time in Chinese history. There was much starvation, and death as there was not enough food for everyone (Chee-Beng 2013; Pan 1998). This is one of the reasons my grandfather had to leave China to make a better living. The push factors of out migration were political instability, poverty, and lack of opportunities. The pull factors of SE Asia were that other ethnic Chinese seemed to be making a better living than inside Mainland China. Yeye's uncle decided to travel to Vietnam and needed someone to be his accountant as "he did not trust the local Vietnamese people." Here I want to reckon and acknowledge these "cultural imperialistic" sentiments ${ }^{4}$; in other words, ethnic middlemen are not pure victims. At times, they can use their privilege to the detriment $t^{5}$ of the local populations ${ }^{6}$.

\section{Cultural Imperialism and Settler Colonialism}

Edward Said's, book Orientalism (1978) goes over the patronizing way that the West has treated and depicted the Orient and its inhabitants for centuries. He defines the Orient as the Middle East, Asia and North Africa which are the source of the Occident's oldest colonies. Orientalism refers to ideas of the Orient's inferiority as an (1) academic field, (2) world view, and (3) political justification for domination (Said 1979). Said asserts that the West uses the Orient as an imaginary to juxtapose and define itself. For example, the Occident defines itself as rational and forward thinking while it relegates the Orient as irrational and backwards. You can see egregious example of Orientalism or western superiority over the east in western art, literature and governing.

Within Asia, there is also cultural imperialistic sentiments such as China viewing itself as superior to other Asian countries. China is named the "Middle Kingdom" so they often will view themselves as the center of the earth and other non-Chinese as aliens. In Cantonese, there are pejorative terms to call non-Chinese, such as "gwái".

4 I would never say this to anyone in my family as it would illicit a huge argument as they tend to view themselves as pure victims. This is similar to how modern Westerners cannot acknowledge that they benefit every day from the social injustice of the past.

5 I have no knowledge that my family ever used their privilege to the detriment of the community. It was just an academic point that because of their class position there can be potential for inequities.

6 Not everyone can travel from country to country so my grandfather must have had some sort of privilege. This is where my familial life and academic training conflict with each other. 
Although it does not fit exactly, one can argue that ethnic Chinese who traveled to SE Asia had culturally imperialistic attitudes and practiced a form of Settler colonialism. Settler colonialism is a form of settlement where the invading group replaces the local population. The British are the best examples of these as their inhabitants have slowly replaced the local population in the United States. The ethnic Chinese did not replace the indigenous Southeast Asians, but they used their Sino-networks to establish businesses and interacted and "trusted" only other ethnic Chinese. This created a closed Cantonese loop, and considerable resentment by the indigenous Vietnamese populations. I see settler colonialism ideas and attitudes in my family in that they tend to compare country to country in how well the Chinese can do business there.

There are examples of Chinese in SE Asian countries, such as Indonesia who have experienced murder and molestations by the local inhabitant when the economy was in a downturn (Osman and Hayanto 2010). In total, 50\% of the Chinese community in Cambodia were killed by the Khmer Rouge due to economic resentment and cultural problems. ${ }^{7}$ My larger point here is that these closed Chinese business circles can build up a lot of resentment in indigenous communities that they settled in. They can be easily scapegoated for all the supposed wrongs within the country.

\section{1935 Saigon, Vietnam}

In Vietnam, I imagine my grandfather experienced cultural shock while hearing a different language and seeing a drastically different people. He was a stranger, an immigrant, a flaneur in this new country of Vietnam. I am certain his goal was to return to China after he made money. In this sense, grandfather is no different from the other Chinese males of the diaspora, who go abroad, but have dreams of returning home as success stories (Takaki 1989; Pan 1998). They endure racism—or prejudice in this case—for the benefit of their future descendants. Sometimes, they take a local wife but not my grandfather. He had Chineseness in his soul. ${ }^{8}$ Did he pass that on to me? Can someone hold five thousand years of Chinese culture in her body through their food or language?

After he became economically successful, he travelled back to China to find a wife. There, he was "matched" with my spoiled 16-year-old grandmother. Her father (my great grandfather) married an additional wife so that he could produce a male heir, but that never happened. Thus, she had two mothers and a father who doted on her as an only child. It was customary for the upper classes to bind the feet of their daughters, but their family refused to disable her in this way (Shepherd 2019). I am so proud of these ancestors that they defied the common culture and would not bind my grandmother's feet. Though I must say she had tiny feet and hands that she has seemingly passed on to my daughter.

My grandfather worked and worked; as family folklore has it, that work ethic allowed him to establish multiple businesses that flourished in what would become Vietnam. Family lore also points out that he never had a mistress, something of a rare feat for a wealthy man of his generation. My other maternal grandfather cannot say the same; he had many mistresses. But this piece is not about my mother's side of the family. My grandfather owned a steel warehouse something equivalent to a US Home Depot warehouse store in the United States. Here, he sold supplies such as steel for different construction projects.

Tellingly, family lore speaks less of my MaMa (Grandmother) who bore all eight children (six sons and two daughters, including my father who is the second oldest son) in Vietnam. There were babies that did not survive but these are family traumas that would receive silences if you ask anything about it. She worked equally hard to manage the family.

To maintain the Sino-identity, my grandfather insisted on hiring a Chinese nanny for each of his Vietnam-born children despite it being more expensive than having a local Vietnamese nanny. Arjun

7 See (Gellately and Kiernan 2003) and (Vickery 1984).

8 I connect "Chineseness" with taking a Chinese wife to contrast with the many Chinese males in the diaspora who often took a second local wife. They would have a first family in Mainland China and a second family in the new land. 
Appadurai's Translocalities and Ethnoscapes are apropos here. He defines Ethnoscapes as a framework to see that the nation is not just tightly bound borders, but instead fluid cultural pathways. Ethnoscapes are discrepancies, meaning they are illegible spaces (Appadurai 1996). People such as tourists, immigrants, refugees, ethnic middlemen, and other people on the run form this scape (Appadurai 1996). These groups are in a perpetual mental and physical Translocality a "between-betwixt" state. They sometimes hold a culture like my family did that no longer exists (as, for instance, 1915 Guangdong, China). Did it ever? There are a connectivity and change and these groups are always considered marginal and lost in the official history books since no one claims them. My Sino-Vietnamese family were refugees that you cannot clearly define.

It is important to note that the entire family at this time still had Chinese citizenship. When my 84-year-old aunt was a teenager, the Vietnam government issued an edict that in order to keep your businesses and stay in the country you had to become Vietnamese citizens. My father and the entire family at this point all got Vietnamese citizenship while staying culturally Chinese. Aiwha Ong's Flexible Citizenship recounts how many Chinese overseas have multiple passports in many different countries. My grandfather used his economic privilege to send his kids to Chinese schools, not local Vietnamese schools. Thus, my father and his siblings (my aunts and uncles) grew up in a Cantonese bubble "sheltered" from Vietnamese influences. You can see here that the family pride (or excessive jingoism) in Chinese culture also masked their detachment from the local culture.

Where my father's side of the family was characterized by ethnic isolation and cultural retention, my mother's side of the family was more middle class and was more likely to interact, and even blend, with Vietnamese culture. To this day, Vietnamese is more the lingua franca for my mother's younger siblings. Some of my mother's younger sisters settled in Orange County, CA-the largest Vietnamese community outside of Vietnam-and almost exclusively speak Vietnamese; if they speak Cantonese it is with a Vietnamese accent. Some members of this side of the family have intermarried with Vietnamese nationals. My father has long been frustrated when he sees Sino-Chinese who no longer speak Cantonese.

To my surprise, some of my cousins were raised in Orange County, CA, identify as Vietnamese which I find shocking. The Communist Vietnamese government nationalized all businesses and my grandparents had to give up their house and businesses. My grandmother in a last act of rebellion threw the keys of her four-story house into the ocean. All their children were sent abroad years earlier to avoid forced military enlistment. The family urged my grandparents to leave but they had spent a lifetime building up their businesses and my grandfather refused. My grandfather died of cancer shortly after having learned that he would have to give up his businesses. Did he die of a broken spirit? My grandfather's death seemed to suck all the happiness out of our branch of the family and we just went into survival mode, traveling from a nation state to a city state to another nation state. To this day, we are not a happy family, but instead a stoic and ascetic family, patriarchally run by my father. He would constantly tell us that women are incompetent. Fate bestowed my misogynist father with only two daughters, that he raised like sons. This is an example of how our family was battered by not just nation state policies, but also battered within the family.

\section{My Mother? A Silent Being That Loves Me}

I once read a graphic novel called, Are You My Mother? by Alison Bechdel (2013) and unequivocally I knew exactly what the title meant. It meant a daughter who never knew her mother. My mother has been at my side throughout my whole life but she rarely, if ever, speaks. She often tells me not to speak, but the opposite seems to have happened. I often think that she is hard-wired for silence but it did not help that my father yelled at her and everyone in our household. I remember thinking the 
roof was going to fall on us from my father's screaming ${ }^{9}$. Only under the rarest circumstances did my mother ever mention her time in Vietnam. My sister told me that as a child my mother was given away by her parents to her aunt's household. The intense anger I feel over this makes me burn red and I have always been distant from my mother's parents. She must have been terrified to go to another family and I imagine she thought she did not deserve better because she was a girl. I would like to go back in time and hold her hand and tell her, "it would be all right."

All I know was that she was a young nurse in Vietnam. I know this only because I saw a picture of her in a white nursing gown. The picture looks quite formal and my mother looked so young and beautiful. She never spoke of her time in Vietnam other than when she was scolding us for not appreciating our life. When I whined about how hard fifth grade multiplication was, she would say, "Don't complain! Someone threw a Molotov cocktail at me during the war." If I mentioned that I had lost a book she would respond, "You have to be more careful with your things because we lost everything in the war." In our family, we were never allowed to complain as we would always be told that life was horrific in Vietnam and we should be grateful. In fact, when I was much older, I was shocked to realize that she could speak Vietnamese fluently. My mother was born in Vietnam but never identified as Vietnamese unlike her decades-younger siblings who went to local school there. So, unlike countless college freshman who write long, "Who Am I", essays, I have never had any identity shock or confusion about who I was ethnically. For as long as I can remember, my mother reinforced our Chinese identity. I once came home from first grade in Catholic school and declared: "I am black"; this was not identity confusion as much as it was the recognition that I had more in common with the two African Americans than I did with the $98 \%$ of the school that was Anglo. My mother did not appreciate my budding intersectionality; she angrily shook me by my shoulders and said," You are not black! You are Chinese." Because I was a relatively obedient child, I followed what she told me from then on and never objected to this. Years later at age 20 my UCLA roommate asked me if I was Chinese-Vietnamese because of my last name and I said, "What are you talking about? No!" Then my professor asked me if I was a "boat person." I again said, "No" mortified that he asked me that question. I did not realize it until this year that my family was part of the 1970s refugee exodus out of SE Asia. In 1976, Vietnam became communist and over 200 thousand Sino-Vietnamese were forced out of Vietnam- many repatriated to China.

As an undergraduate, I remember reading about historical horror stories of the Thai pirates who robbed, murdered and molested the fleeing Vietnamese refugees never connecting this to my family at all. I never connected these stories to myself nor my family. Silences can be a form of lying. My family did not go through any of those atrocities as we used our economic power and privilege to leave Vietnam before the war even ended. We left in airplanes before the war ended. As with Leslie Sklair's transnational capitalist class (TCC), we had to use every last one of our economic privilege to leave Vietnam that others could not. ${ }^{10}$ Sklair defines the TCC as groups of people who are not linked to a particular nation state, but instead use commerce to work in several countries to further their capitalistic goals. Many TCC are ethnic middlemen or come from ethnic Middlemen families. We left over five years before the war ended and my father was tasked to starting a new life in Hong Kong. We cannot

9 I do not know why my father always yelled at us. He just did. I know he must have experienced a lot of racism. When the man of color is oppressed by the Anglo man, he turns that anger on his family. He always I don't know why my father constantly told us we were "stupid women" and that "women that did not know anything." This is truism of many people of color families: we have to absorb the humiliated rage of our POC men and still protect them. Since he has a significant accent Midwestern Americans probably assumed, he was not intelligent. Kimberly Crenshaw's "intersectionality" is about how different race, class, and genders lead to different oppressions and discriminations. Here is where I part from traditional Anglo first-wave, second-wave, and third-wave feminism as my family was influenced by Confucianism. I.will.never.go.against.my.family. Psychologically I find it impossible to go against other Asians, women, or people of color. See Confucian Weekly Bulletin. Confucian Feminism: The (In)Compatibility of Confusianism and Feminist Ethics 儒家思想 与女性主义伦理的 (无) 兼容性. https://confucianweeklybulletin.wordpress.com/tag/Confucian-feminism/ (accessed on 21 April 2019).

10 READ: We bribed our way out. 
compete against Hong Kongers' as our Cantonese is ancient and "laughable" out of step-whereas my aunt was discriminated against in Vietnam and often asked when she spoke Vietnamese "Are you from China?" When she was in Hong Kong they judgingly asked "Are you from Vietnam?" I rarely went to family gatherings on my mother's side of the family. When I was 22, I did and one of my cousins said that according to international law we were considered Vietnamese and I again said, "That's not true!" My father who despises my mother's philandering father would say that my mother's family was just middle class and thus they mixed too much into Vietnamese culture. All of these questions about a possible Vietnamese identity came to a head when I went home and confronted my mother. Is this true? Are we Vietnamese and she said, "No." Then I told her that my aunt said that my grandmother on my mother's side was partly Vietnamese. She told me that I was an infinitesimal amount Vietnamese, and it did not mean anything. She also told me to never tell my father because he would get angry. The larger point here is that my family hides a lot of information and that has even trickled down to the next generations. I have noticed that my generation of cousins are also secretive, flexible, assertive, and vague. They also have varying identities as some identify as fully Vietnamese to partly Chinese-Vietnamese to fully Chinese according to the situation. This chameleon adaptation to different environment is something that is passed down from the middle man ethnic families.

\section{1969 Hong Kong, (Then a British Colony)}

Before my parental grandfather died, he sent my father to Hong Kong. Family secrets reveals he was some type of stock broker, but I do not know if this was true. He must have experienced a significant culture shock when he was engulfed by fast paced Hong Kong life. This year, I realized my father did not read mainstream or academic Chinese well since he failed his DMV exam several times in Chinese. He dropped out of French boarding school when he was in the 8th grade and instead told his father he would rather work. My uncle Luk Suk (sixth uncle) once said to me, "I have an accent in every language I speak!" I did not understand what my uncle meant, but I have a better understanding now. Our family is neither here nor there in terms of having a fixed cultural background. Homi Bhabba's migrant theory of "hybridity" — an ethnic in-betweenness is a place my family floated around in many countries (Bhabha 1994). The Cantonese they learned in Vietnam was ancient and out of step with Mainland Chinese norms. When they went to Hong Kong, everyone could hear their ancient Cantonese with Vietnamese inflections. I suspect now that my family could not compete against local Hong Kongers who are so brilliantly urbane.

I once interviewed a Hong Kong Chinese woman who said her greatest prejudice was against the flood of "boat people" refugees who consisted of Sino-Chinese who came from Vietnam to Hong Kong. I realize she was talking about my family. Growing up, my parents never told us we were from Vietnam and when we were old enough to ask, my mother would say, "Don't tell anyone we are from Vietnam. Chinese people look down on Chinese from SE Asia." I even hear this now on my other side of the family. "Don't tell people we are from Vietnam!" I heard my aunt tell her daughter in 2018.

This "middleman minority" family motto is to always improve the lot of the family. We do this by moving, accumulating information, and hypergamy. Susan Ossman would call our family "serial migrants" who go from country to country (Ossman 2013). Ossman's book, Moving Matters is complex and goes beyond the simple binary of home country and the new immigrant country. She writes about how you "accumulate" new knowledge in each country that you settle in, and you then bring that knowledge to third and fourth countries. There is no single story of why migrants move and it is not always simple reason like economics or wars that push people to go to different nation states. It is no accident that four of my cousins and my sister have married Taiwanese and Hong Kong Americans who are considered "higher class" Chinese. These marriages are considered acts of marrying someone of a superior class and culture. 


\subsection{Chinese Hierarchies}

Ali Wong is a Chinese-Vietnamese comedian and writer for the television show, Fresh Off the Boat and the Netflix special Baby Cobra (2016) and Hard Knock Wife (2018). She tells a joke of how her mother is Vietnamese and father is Chinese. She married a Harvard MBA who is half Japanese and half Filipino and they have an unspoken knowledge about themselves. Her joke is that they are both "half fancy Asian" and "half jungle Asian."11 East Asia such as Japan, Korea and China are on top of the Asian hierarchy and also outer Sino-dominate spheres such as Taiwan, Hong Kong and Singapore. The "jungle Asians' are primarily from SE Asia" are usually at the bottom of the hierarchy, partly because SE Asians are generally phenotypically darker-skinned. Also, throughout East Asia there are many SE Asian domestic workers who are imported to do domestic work and manual labor (Constable 1997).

My mother always told me to marry someone from Hong Kong or Taiwan but never Mainland China as they might be too chauvinistic or impoverished. It is interesting to contrast this with the cases of new 1990s' millionaire Mainland Chinese who are going all over the world buying houses-a global gentrification which displaces other old-time Chinese populations. The point here is that improvement of the family economics and culture is of utmost priority.

\subsection{Hidden Figure: Aunt Sharon Saves Us All}

My aunt worked as a secretary for the US Army. Her education in Chinese schools and a French boarding school privileged her with some fluency in Vietnamese, Cantonese, Mandarin, Hakka, French and English. Suffice to say, many "middleman minority" families have forked tongues. Tara Yosso's work on community cultural wealth is important here (Yosso 2005). Yosso's work identifies linguistic fluency as a type of wealth that a community can have that is not economic. Her work talks about story telling as a form of resistance capital. My aunt is the untrained oral historian in our family and she tells all the stories in our family. Since I was a child, she would constantly tell us all that we had lost in other nation states and how we are so lucky to have immigrated to the US. She gives dramatic pauses, with often comedic timing, about how we have to work hard and study, but she herself was bad at school. This gave me a lot of solace as a child since I got bad grades in first grade.

Most of the knowledge I have about my family is from stories from her. I have interviewed her, my cousins, and my grandmother many times for other publications (Banh 2019). My aunt Sharon has no children so I and my other cousins are her spiritual children. My father gets angry at her for talking to me. She tells me because of her ability to speak many languages, she was hired by the US Army as a secretary. Seeing how the Vietnam war might end with the Communists winning, she did not want to stay in Vietnam as she knew she would be the target of attacks for her employment. So, she was sponsored by an elderly retired major in Tacoma, Washington, and then sponsored all of us. My father and his sister's family all arrived in New York because that is where their Christian sponsors lived.

\section{1975 Long Island, New York}

My father and mother arrived in New York and immediately obtained custodial and sweatshop jobs respectively. My father cleaned windows and swept floors. My mother pulled electric cords through lamps. Their work life took turns as my mother worked day shifts and my father worked night shifts. Of course, my sister and I would be up during the day and that would anger my father when we made any noise.

My parents scrimped and saved and were able to save enough to move to the Midwest to try their hands at opening a Chinese restaurant. As an adult, I asked my mother why we were raised in an all Anglo and African American Catholic space. I have been told many stories so I am not certain

11 See Ali Wong's hilarious, Netflix special (2016), Baby Cobra which chronicles her travels though sexuality, pregnancy and "trapping" her husband. See Netflix.com. 
which story is true. My mom would interchangeably say, "Baba moved us to the Midwest because it was too competitive in New York and American people don't know Chinese food so it was easy to start a business." Sometimes she would say things like, "Baba never wanted to see any Asians again." Was that war trauma talking? I will never know the truth of why they chose to move to the Midwest, because they became angry whenever I ask them questions.

\section{1980 Bellevue, Illinois}

I grew up in a Chinese Restaurant. It was the lifeblood of our family for a long time. When I was young, my sister and I peeled frozen shrimp and our six- and our eight-year-old little fingers froze while we were doing it. I hate shrimp to this day because I associate it with icy fingers. ${ }^{12}$ We were certainly verbally discriminated against when we lived in Bellevue, but my mother also told me to ignore everything, and so I did. Like many children of immigrants, I often acted as an informal translator for my parents; however, when my parents asked me to translate a customer's racist comments or actions, I knew it would only upset them so I always said something innocuous: "They just wanted more napkins."

Some might say I was an eight-year-old cultural broker for my "middleman minority" family's fourth migration leg (Jezewski and Sotnik 2001). Mary Ann Jewzeski and Paula Sotnik define a "culture broker" as someone who mediates or bridges between different groups and that is what I did before I remember I was even a person. Like many of my students of color, I was the "interpreter" for my parents my entire life (Jezewski and Sotnik 2005). Growing up as a cultural and linguistic translator for my parents made me feel much older than I was.

I have always been protective of my family. This has generalized to feeling I have to protect other Asian people and people of color. This is when my love of anthropology started. It is no accident that I am an Anthropology and Ethnic Studies professor now; the roots were in my upbringing. My father called me "little sister" or mui mui (little sister 妹妹) growing up so I thought I had a high stature in my household never knowing until I was an adult that Chinese people refer to each other not by names but by relational terms: how you are situated in the family. I was the younger sister, so they called me little sister, but in my convoluted child mind I thought it meant I was my father's direct younger sister which meant I had a higher status than my older sister. I enjoyed internal pride over this misunderstanding my entire life.

Our time in Bellevue was bucolic but also stoic. We were never allowed to speak English at home and we could only speak Cantonese to each other. We went to Catholic school. I sensed I was different, but I could never put a finger on it. My only memory of seeing Chinese people (or any Asian people) was when our cousins from Missouri (they also owned a Chinese restaurant) visited us (or vice-versa). Consequently, as a child I thought that every Asian person was a relative. Even today, I have to do a double-take to dissuade my brain from thinking this. It is not lost on me that what one generation tries to hide, the next generation seeks out as I am now an Anthropology and Asian American studies professor.

\section{Food Genealogy in the Chinese American Restaurant}

Owning a Chinese restaurant in Bellevue, Illinois helped my family maintain Chinese language skills, work ethic, and identity (Jung 2011). In the Midwest, there were no Asians where we were located so ethnicity was a moot point. Being in the Chinese restaurant, we never ate the food we served to customers. There were items called St. Paul sandwich which was a large egg patty on top of white bread. There were other things we sold like fried rice, chop suey, and egg foo young that now sound like alien foods to my adult self that has made several trips to Hong Kong and China to eat traditional Chinese cuisine. I am sure Chinese people would be horrified by these concoctions based on local

12 Even if I look or think about shrimp, my finger instantly feels icy and I clench them. I tell people I don't eat shrimp because of global warming, but it is really because it makes me remember my childhood labor. 
midwestern community ingredients. Famous Chef, Martin Yan, argues that restaurants have to survive and you have to sell whatever the community will eat. ${ }^{13}$ Today, one of my cousins still likes to eat these Americanized dishes at successful American Chinese food chains like Panda Express.

There are double menus at Chinese restaurant: One for Americans and another for Chinese people. At our restaurant, our parents cooked us different things from what we sold. We ate white rice with beef and tomato stir-fry. There was the occasional steamed fish dish with ginger soy sauce, and a delectable mapo tofu dish. Stir-fried beef with flat rice noodles and a minced pork patty were mainstays as well as soothing weekend congee that was always served with a fried egg and pork floss. My parents showed us love through food and we always ate well. My parents never bought us books or toys, nor did we ever celebrate Christmas but food was always on the table. I believe I was spoiled by having never having to worry about food. To me, Chinese food is a direct genealogy to my ancestors' culture, history, and life. When I eat Chinese clay pot rice, my eyes get misty because I know all global old timer overseas Chinese people eat it to feel closer to a bygone past. I know traditional Chinese flavor profiles and can tell if the food is a fusion of different cultures.

\section{Three Theories That Apply to My Middleman Family: Serial Migration, Community Cultural Wealth, and Cultural Capital}

Three combined theories can apply to my family transnational migration story: Susan Ossman's serial migration, Tara Yosso's work on community cultural wealth theory and Pierre Bourdieu cultural capital. Susan Ossman's serial migration theory of "accumulating" new knowledge in each country you visit with is something my family experienced. When talking to my uncles and aunts, they mention how the Chinese were discriminated against in Vietnam. Today, I think that discrimination was a psychological "bridge" (or cognitive protective cover) that helped us survive the Midwest American racism. In Vietnam, we were the minorities and now we were again the minorities in a different country. Our family did not miss the country we had left and in fact never spoke of our time there. This makes us very different from ethnic Vietnamese who left their country with regret and sorrow.

Tara Yosso's work on community cultural wealth is also applies in that my middleman family speaks many languages and has many stories of how we survived in quite desperate and hostile spaces. Pierre Bourdieu's "cultural capital" theory also applies in that my family learned new skills in each country that we stayed in. Bourdieu defines cultural capital as "skills, tastes, clothing, mannerism etc." of a certain class that can form a certain identity that others may share (Bourdieu 1984; Richardson 1986). For example, my family has certain business acumen and linguistic traits that have been passed down intergenerationally. Many of my family members are natural "salesmen" for various things. Most of my cousins, who had high school or less educated parents, are very successful doctors, lawyers, and businessmen who went to elite colleges. I have a $\mathrm{PhD}$ and am a professor. My best friend Herb once told me that he thought a professor was a type of "middleman." We are all hustler-middleman in different fields, and I mean that in the best sense of the word.

Our "middleman minority" family had definite business skills or Bourdieu's "social capital" that we could transfer over to the new country (Chan 2004). I found it incredible that my cousins owned a grocery store in Vietnam and then reopened another grocery store in Missouri. Our cousins also owned a Chinese restaurant like our family did. The skill set of trade and commerce could be transferred from country to country. We were also very aloof from the American social life as we were from the Vietnamese social systems. For example, my father prides himself on never taking any welfare and we never voted. ${ }^{14}$ Somehow, we survived in the Chinese restaurant, probably making less than $\$ 20,000$ a year.

13 See full interview of Chef Martin Yan (2002) in Banh, Jenny and Haiming Liu, 2019. American Chinese Restaurant: Consumption, Culture and Society, London: Routledge.

14 I vote in every US election and I volunteer to register voters when I can. 


\section{1985 California}

My father was told by my mother's sister that life was better in California, with more opportunity. We left the Midwest and I experienced culture shock when I met my first Asian Americans. A school mate came up to me and spoke Mandarin; I blanched with shock. During this time, I met my maternal grandparents, and they often spoke Vietnamese, which my father did not like. He had passed on his language prejudice to me and I often was also unhappy when Vietnamese was spoken around me. Later, I made Chinese-Vietnamese and Vietnamese friends, including a couple of lifelong girlfriends, when I was an undergraduate at UCLA, so I was able to overcome the discrimination that I was taught. These experiences taught me that prejudice can be passed down in families, but they also can be broken in subsequent generations.

While in California, my father left the restaurant world and became a businessman (again) and did much better financially; eventually, we were able to buy a house and I got to go to school with middle and upper middle-class minorities. I felt quite different from them, as I grew up working and they would tell me stories about how they went on Disney cruises or trips to Taiwan. Their Taiwanese or Hong Kong parents went to college and did not work with their hands as my parents had. My classmates' parents also spoke English, which my parents did not fluently. However, while those language skills might translate into a greater familiarity with mainstream American culture, and maybe even greater opportunities, their parents' English fluency often meant that my Asian and Asian-American friends lost their ethnic tongues. In contrast, growing up in a Chinese restaurant protected me from linguistic erasure and taught me that hard work was a valuable tool when adapting to the challenges of school. This might seem antithetical to the Model Minority Myth, but I was also taught that education was not the most important thing. Instead, making a living and supporting the family, with your hands if need be, was the most crucial. I tried to endure and never gave up. I am a hard worker like my ancestors and descendants. I was a passable student with fits of writing here and there. But somehow, I knew I was from Hong Kong, even if it was in a simulacra way; I made it a point to do my PhD fieldwork in Hong Kong.

\section{2012 Fieldwork: Back to Hong Kong}

I experienced culture shock when I went to Hong Kong for my anthropological fieldwork. I wonder now was it something similar to what my grandfather and father/mother felt years ago? In 2012, while carrying out my anthropological fieldwork, I met Sino-Vietnamese custodial workers. When they heard my Cantonese, one of the women asked me if I was a "Chinese Vietnamese overseas bridge" (Zhōngguó yuènán qiáoliáng 中国越南桥梁) and I, to my own astonishment, said, “Yes." As a graduate student with a young family, I finally arrived in Hong Kong-although my parents had told me not to go. They said Hong Kong was dangerous and the people untrustworthy, but I soon discovered the opposite. During my fieldwork, I was able to travel to Vietnam to look around, but I felt nothing. Only ghosts are there and I did not dare to ask where my grandparent's old house was. In Hong Kong, I walked with my eight-year-old daughter and six-year-old son and told them that our family had lived here for a time and that they must come back if things go south in the United States. Because of significant effort on my part (with a great deal of assistance from my parents), my kids can speak both Cantonese and Mandarin and write Chinese characters, something I think is a minor miracle given the increasing dominance of English in my own life. Just like my grandfather preached the importance of language retention to my father, I pushed language fluency to my children. If asked, I often say that these language skills are important for practical reasons (being able to compete in a global labor market, for example) but between you and me, given my family's history, I see my kids' language skills as a survival tool should they ever need to escape to a Chinese-speaking part of the world. I constantly remind myself and my children of a quote from Aiwha Ong's Flexible Citizenship where a Chinese diasporic man says something along the lines of: "I can live anywhere in the world as long as it is close to an airport" (Ong 1999). 


\section{2016 Time Is a Circle: San Gabriel Valley, CA}

My parents, sister, cousins, and for a time my own family, lived in California's San Gabriel Valley, the famous Chinese culinary capital colloquially known (from its telephone area code) as the "626." Unlike me, my kids have grown up around diverse and authentic Chinese food created and consumed by Chinese ethnics just like us-overseas bridges or Hua Kiu (Hua Kiu means Chinese "overseas bridges") who live outside of China In communities like Alhambra, San Gabriel, Monterey Park, and Rosemead, you will find Chinese Vietnamese, Chinese Cambodians, Chinese Indians, Chinese Indonesians, Chinese Filipinos, Chinese Thai, Chinese Malaysians, Chinese Burmese, etc. (Chan 2004). ${ }^{15}$ They all have family stories very similar to mine because their families also had businesses in SE Asia and they had to flee when the local population turned on them. They are also successful runners, but they all bear scars from their time in SE Asia. Like my family, many are secretive, distrustful, and fatalistic. When I go into donut shops invariably owned by Chinese-Cambodians, I remember that around half of the Chinese Cambodian population was killed in the Cambodian genocide and forced labor camps. My Chinese Filipino friends relate stories of kidnapping attempts on them. My Chinese Indonesian friends speak of the mass rapes that the Chinese-Indonesians were subjected to and how even the police officers stabbed Chinese Indonesians in the stomach. My observation is that many of these SE-Sino groups also harbor similar ambivalence to negative opinions of the local community they fled from.

Today, I teach at a university that is predominately SE Asian American with many Hmong, Mien, Laotian, Vietnamese, and Cambodian diasporic students (Dufoix 2008). ${ }^{16}$ These students are "double minorities" like myself. I define double minorities as minorities within minorities that are often non-legible in standard categories. They are second generation SE Asian Americans, many of whom are part Chinese who are trying to make their way. They have family secrets too, but they all survived, and I am sure their genetic makeup has been transformed from those experiences. Ready to pass to the next runner generation.

I try to teach my children that they have to flee if things get bad and they can start again if they need to. If they "work hard" and put their heads down, they can start again from nothing, anywhere in the world and be successful. I acknowledge the "putting your head down" plays into the Model Minority Myth of Asians being "over-competent but forever foreigners" so it is my struggle to go against this sentiment that I was taught. I teach my Ethnic Studies students that Asian Americans are used as a sword to wound African Americans and other people of color. The Asian American "Model Minority" is a myth that serves to divide and conquer people of color in the United States. ${ }^{17}$ Anagnostou (2003) writes on "Model Americans" in Diaspora journal: on the "price" of certain kinds of identification in the assimilation context, which have psychological costs as well as particular advantages.

Time is a circle. It is in my blood to go from country to country and start again. I have confidence that I can do it and I have to keep this spirit alive in my descendants that I received from my ancestors. Since time is a circle, we are due to migrate to a different country soon.

Funding: This research was funded by California State University, Fresno College of Social Science faculty grant.

Acknowledgments: I would like to thank the two anonymous reviewers and also editor Philip Q. Yang for his sage direction. I would like to thank Sean Slusser, Eugene Anderson, Haiming Liu, Genevieve Beenen, and Ray Pun for offering sage advice. I would like to thank Melissa King and Aurora Chang for giving me much needed theoretical leads.

Conflicts of Interest: The author declares no conflict of interest.

15 This is not including the old-time Chinese populations from Hong Kong and China and now newly arrived Mainland Chinese. There has been a lot of disputes between the old time Chinese and the new Mainlanders who are demolishing houses and building huge mansions obscuring the view of others. They also drive up the home prices for many people in the 626.

16 My university also had Oaxacan Mexicans who are an indigenous group in Mexico. I especially identify with them as they are also double minorities.

17 Asian Americans did not invent the Model Minority term. See Success Story, Japanese-American Style By William Petersen. New York Times. Jan 9, 1966; ProQuest Historical Newspapers The New York Times (1851-2006) p. 180. 


\section{References}

Anagnostou, Yiorgos. 2003. Model Americans, Quintessential Greeks: Ethnic Success and Assimilation in Diaspora. Diaspora: A Journal of Transnational Studies 12: 279-327. Available online: https://muse.jhu.edu/ (accessed on 3 June 2019).

Anderson, Eugene N., and Barbara Anderson. 2012. Warning Signs of Genocide: An Anthropological Perspective. Lanham: Lexington.

Appadurai, Arjun. 1996. Modernity at Large: Cultural Dimensions of Globalization. Minneapolis: University of Minnesota Press.

Banh, Jenny. 2019. Chinese Restaurant Kids Speak About Labor, Lifeways and Legacies. In American Chinese Restaurant: Society, Culture, and Consumption. Edited by Jenny Banh and Haiming Liu. London: Routledge.

Bechdel, Alison. 2013. Are You My Mother? A Comic Drama. Indianapolis: Mariner Books.

Bhabha, Hommi. 1994. The Location of Culture. London and New York: Routledge.

Bonacich, Edna. 1973. A Theory of Middleman Minorities. American Sociological Review 38: 583-94. [CrossRef]

Bourdieu, Pierre. 1984. Distinction: A Social Critique of the Judgement of Taste. Cambridge: Harvard University Press. Bui, Thi. 2017. The Best We Could Do. New York: Harry N. Abrams.

Chan, Sucheng. 2004. Survivors: Cambodian Refugees in the United States. Urbana: University of Illinois Press.

Chan, Sucheng. 2006. The Vietnamese 1.5 Generation: Stories of War, Revolution, Flight, and New Beginnings. Philadelphia: Temple University Press.

Chee-Beng, Tan. 2013. Handbook of the Chinese Diaspora. New York: Routledge.

Constable, Nicole. 1997. Made to Order: Stories of Migrant Workers. Ithaca: Cornell University Press.

De Mente, Boye Lafayette. 2009. The Chinese Mind: Understanding Traditional Chinese Beliefs and Their Influence on Contemporary Culture. Clarendon: Tuttle Publishing.

Desai, D. R. Sar. 2009. Southeast Asia: Past and Present. Boulder: Westview Press.

Dufoix, Stephane. 2008. Diaspora. Oakland: University of California Press, pp. 46-50, 72-74.

Gellately, Robert, and Ben Kiernan. 2003. The Specter of Genocide: Mass Muder in Historical Perspective. Cambridge: Cambridge University Press, pp. 313-314.

Hancock, Ange-Marie. 2013. Solidarity for Millennials: A Guide to Ending Oppression Olympics. New York: Palgrave Macmillan.

Jezewski, Mary Ann, and Paula Sotnik. 2001. Cultural Brokering: Providing Culturally Competent Rehabilitation Services to Foreign-Born Persons. Buffalo: Center for International Rehabilitation Research Information \& Exchange.

Jezewski, Mary Ann, and Paula Sotnik. 2005. Culture and Disability Services (with a Focus on Culture and Foreign-Born Characteristics). In Culture and Disability: Providing Culturally Competent Services. Edited by John H. Stone. Thousand Oaks: Sage, pp. 15-31.

Jung, John. 2011. Sweet and Sour: Life in Chinese Family Restaurants. Cypress: Yin and Yang Press.

Kingston, Maxine Hong. 1975. The Women Warrior. New York: Alfred A. Knopf, p. 1.

Lipner, Julius. 2012. Hindus: Their Religious Beliefs and Practices. New York: Routledge.

Marx, Karl, and Friedrich Engels. 2019. The Communist Manifesto. New York: Penguin.

Ong, Aiwha. 1999. Flexible Citizenship: The Cultural Logics of Transnationality. Durham: Duke University Press.

Osman, Urfika, and Ulma Hayanto. 2010. Still No Answers, or Peace, for Many Rape Victims. Jakata Globe. May 14. Available online: https://web.archive.org/web/20100904160043/http://www.thejakartaglobe.com/ national/still-no-answers-or-peace-for-many-rape-victims/374845 (accessed on 1 June 2019).

Ossman, Susan. 2013. Moving Matters: Paths of Serial Migration. Palo Alto: Stanford University Press.

Pan, Lynn. 1998. The Encyclopedia of Chinese Overseas. Cambridge: Harvard University Press, pp. 228-33.

Richardson, John. 1986. The forms of capital. In Handbook of Theory and Research for the Sociology of Education. New York: Greenwood, pp. 241-58.

Said, Edward. 1979. Orientalism. New York: Vintage.

Shepherd, John Robert. 2019. Footbinding as Fashion: Ethnicity, Labor, and Status in Traditional China. Seattle: University of Washington Press.

Takaki, Ronald. 1989. Strangers from a Different Shore. New York: Back Bay Books.

Vickery, Michael. 1984. Cambodia: 1975-1982. Boston: South End Press. 
Wang, Gungwu. 2002. The Chinese Overseas: From Earthbound China to the Quest for Autonomy. Cambridge: Harvard University Press.

Yan, Martin. 2002. Martin Yan's Chinatown Cooking: 200 Traditional Recipes from 11 Chinatowns around the World. New York: William Morrow Cookbooks.

Yosso, Tara J. 2005. Whose culture has capital? A critical race theory discussion of community cultural wealth. Race Ethnicity and Education 8: 69-91. [CrossRef] 